\title{
Research on the Aim Value's Variation of Yen Fu's Constitutionalism Political Thought
}

\author{
Yang Yang \\ Southwest University, Chongqing, China \\ Email: yangkent78@qq.com
}

Received 9 August 2015; accepted 12 September 2015; published 15 September 2015

Copyright (C) 2015 by author and Scientific Research Publishing Inc.

This work is licensed under the Creative Commons Attribution International License (CC BY). http://creativecommons.org/licenses/by/4.0/

(c) (1) Open Access

\begin{abstract}
The aim value for the intellectuals' constitutionalism political thought shared the variation attribute under the circumstance that it was no great change for three thousand years at the end of the Qing dynasty. It was appeared for the value of freedom and order in the early time of Yen Fu thought, but the freedom and order as the implicit aim value were covered by the wealth and power as the visible aim value in the condition that the national salvation dominated all else. In a word, there are a vertical static value genealogy and horizontal dynamic value relation in which the wealth and power, freedom and order are as the aim value and have been changed with the passing time in his constitutionalism political thought, that is to say, his ideal that surpasses to simply pursue the value of wealth and power is to never give up.
\end{abstract}

\section{Keywords}

Variation, Wealth and Power, Freedom, Order, Constitutional Politics, Aim Value, Prosperity

\section{Introduction}

Firstly, the question about the aim value for the intellectuals' constitutionalism political thought under the circumstance that it was no great changes for three thousand years was appeared. For the intellectuals who were lived in the end of the Qing dynasty, their first task was to seek the national wealth and power and national revival. So, the constitutionalism politics that was regarded as a cultivated thought to make country become richer and make people become stronger was brought into China. Did the intellectuals who supported the constitutional politics during that time only care about the wealth and power? Or, were the wealth and power, the ultimated value, in their minds? Later, many intellectuals advocated the civil rights and the regional autonomy, which were not just a tool or a means in their view. They would pay less attention to the value of wealth and power in a certain events or a period of time that the intellectuals were experienced. However, it is becoming more neces- 
sary to understand and learn the recent constitutional practices for one hundred years which have contained the Chinese classical legal tradition, the socialist legal tradition and modern Western legal tradition for the research of the other aim value on what is the other aim value and why we pay attention to them. Secondly, the selection for the research object. Why does the thesis regard the thought and practice of Yan's constitutional politics as the studied core? At the end of Qing dynasty which was visible for the internal disturbance and external aggression in China, his thought and practice about the constitutional politics were an outstanding example among them when the early modern intellectuals began to seek for the difficult road of the constitutional politics. More narrowly conceived, as professor Shi Huazi pointed out that he was standing out of political actions. His practice about constitutional politics was achieved by commenting rather than practicing. More broadly conceived, he himself has also taken part in a series of activities about constitutional politics, such as teaching the Western learning, assisting to build a Russian school in Tianjin, creating a daily-Guo Wen Newspaper and a weekly-Guo Wen Hui Bian, and translating masterpieces. However, it is still obvious to see for his negative actions and he has even been accused of Being a Talker rather than an Actor, so the research value of his thought is much higher than that of his practice. This paper will divide his thought and practice about the constitutional politics into three periods to study. The early stage is from 1895 to 1897; the mid stage is from 1898 to 1910; the late stage is from 1911 to 1921.

\section{The Variation of Aim Value about the Constitutionalism Politics}

\subsection{To Seek for the Wealth and Power in the Early Stage}

Under the historical background that the national capitalism has developed, the national crises is gradually deepened and the government rule is becoming more and more incompetent at the end of Qing dynasty before the reform movement of 1898, Yen fu like other intellectuals of western and reformists all hoped to achieve the national prosperity through establishing the constitutional politics, revitalizing the business and resisting the foreign aggression. Through his accumulation of learning and experience for several years, Yen fu has published a series of fierce political essays such as On the Urgency of the Changing World in 1895 which expressed his initial thought about the constitutional politics-called freedom and democracy out and formed the thought about constitutional politics that treats the wealth and power as the aim value.

Firstly, he pointed out that the pattern difference to run the country between China and Western countries would lead to the national condition run the opposite direction of achieving the wealth and power. The great difference to run the country between China and foreign countries is that Chinese paid more attention to yesterday while Westerns laid more emphasis on today... (Wang, 1986) [1]. On one hand, the Chinese lay stress on copying old things while Westerns focus on innovation to make the knowledge update in academic aspect. The Chinese accept the cycle fatalism-peace and riot or ups and downs are cycling in a country, yet Westerns work hard to explore the political system that will keep the country prosperous for a long time on the system of governance. On the other hand, the ruler in the old time selected governors through the imperial examination to lecture the people in culture and morality. And the imperial examination itself only emphasized the moral cultivation and the ruling means of candidates, which finally led to the disappearance of people's vitality and initiative and made the social life lie in a low level for a long time to maintain the low level of ruling order. Based on the contrast between these two governance pattern, he considered that the result could only be led the economic development remain stagnant for long term and their vitality is unable to be stimulated by the old system as the people is the passive role in old China. There is a mushroom growth in the western countries after the constitutional politics is established.

Secondly, the co-governance with people is realized to finally achieve the wealth and power only if the constitutional politics is established. Of course, there are a prerequisite for the co-governance with people. It would be the first task to give the people freedom under the circumstances of the people's intellectual level at the end of Qing dynasty, as Yen Fu once put that there are differences between freedom and without freedom. It is the basis for giving people freedom that make people become more intellectual, more strong and health and more moral. The basic concept of constitutional politics can be accepted by People to understand the relevant knowledge about constitutional politics through making people become more intellectual, and the social consensus can be achieved before the political reform to pool the strength of society. It is the way to solve the difficult situation that China was forced to be an opium importing country and the weakness of people and army led to the failure of war after two opium wars for making people more strong and health. It is for making people more 
moral to cultivate the citizen's subject consciousness and public awareness which the constitutional politics need. The soul of science is pursuing the truth and the core of democracy is not autocratic, which are similar to the Chinese culture, but why can't we carry out these thought like western countries (Wang, 1986) [1]? This is because people do not change from a subject to a citizen, they do not form the subject consciousness which includes rights, freedom, equality and participation and the public awareness which contains laws, negotiation, the social morality and patriotism. The second task is to perfectly deal with the relationship between the emperor and the people, as Mencius once said that the people are the most important element in a state, the next are the gods of land and grain and the least is the ruler himself. The congress is established to act as the bridge to communicate and co-govern between the rulers and the subjects.

\subsection{Relying on Freedom in the Medium Term}

He has chosen the translation as his lifelong career in the mid stage is from 1898 to 1910. A series of masterpieces translated by Yen Fu has become the classical literature for later constitutional politics. Freedom in this time has not been the way to realize the wealth and power, but has become the aim value of his thought about constitutional politics. Three important elements to realize the freedom are the freedom's condition, conduct and safeguard that are all presented in the famous books translated by Yen Fu and form a distinctive value system about freedom.

Firstly, the conditions to realize the freedom. Although there are no author's note in translations for John Mill's book - on liberty, he explained the conditions of freedom in his translation book in details that everyone has freedom after entering the society, but if there are no limitations for freedom, the society will be full of conflicts. So there must be a dividing line among everyone's freedom, which is the same as the moral standards in Great Learning that talented people rely on to make the society peaceful (Wang, 1986) [1]. He put freedom in the society and professionally explained the conditions of freedom from a passive perspective and he thought that freedom is a space for people to avoid different unreasonable limitations and to choose by themselves.

Secondly, the realization of freedom needs the initiative action of people. The rights of freedom for citizens may be equal in law, but the value of freedom for them is different among them. Yen fu has said that the people fight for freedom from aristocrats under the rule of aristocrat and people fight for freedom from emperors under the rule of emperor, but under the system of constitutionalism and democracy, people will not fight for freedom from aristocrats and emperors who are limited in law at this time and they should strive for freedom mainly from the society, the nation and the current fashion (Wang, 1986) [1]. He points out that no matter aristocrats, emperors or society, nation and current fashion all should stop outside the field of personal freedom.

Thirdly, the realization of freedom needs the protection of political system. The political freedom is established on the certain separation of legislative power, administrative power and judicial power (de Montesquieu, 1959) [2]. According to the theory of dividing power proposed by Montesquieu, Sun Yat-sen came up with the separation of power and divided the state political power into two parts. The one is Quan or called regime, the other is Neng or called governance. Although the personal freedom is endowed by god, only by reasonably and effectively controlling the power of government can the individual freedom finally realize.

\subsection{Expecting the Order in His Late Period}

When Yen fu came into his old age, his political thought about constitutionalism was also in the late period. He, at this time, as professor Zhang Kaiyuan described that constitutionalists and the upper merchants of southeast area always lack the courage of living on their own, they reposed the desire of innovation on some existing strong groups. Therefore, after the collapse of Qing dynasty, it is natural for them to expect that Yuan Shikai can unite China and realize their dream of innovation and development achieved in a stable process. Based on the needs of authority for people in the trouble time and the traditional culture, the value of order became prominent for intellectuals like Yen fu. On one hand, he knew quite well that to realize the prosperity with constitutional politics at this time, the most important task is to enlighten the public and reforming the society which needs an orderly state under an authoritarian government, and to achieve freedom at this time, it is necessary to have a powerful government which can represents the country to start social governance. The formation and operation of government is the cost people have to pay in order to live an orderly life, besides, the freedom must be obtained in an orderly society (Stan, 2004) [3]. He considered that these situations finally made it more difficult to start the social integration and it will be worse for constructing the political center that the constitutional politics 
need. On the other hand, he has been thinking about the path to keep prosperity under the constitutional politics in his old age. Seeking the prosperity is temporary while the sustainable development and keeping the prosperity is permanent. So it is the core that how to form a rational prosperity-remaining order. After having a meeting for more than two weeks, the advisory council now became powerless. He said that they must resign and they would be dissolved by themselves if their resignations were not allowed (Sun, 2003) [4]. In the places of parliamentary democracy where the elites of constitutional politics gathered, the intellectuals neither had the compromising consciousness nor had an authority to command, which led to an incomplete cycling path for political freedom and the gradually depleted resources. Therefore, it is quite difficult to form a prerequisite for the pursuit of prosperity, then it will be unavailable to own an orderly life to remain the prosperity.

\section{Conclusion}

Generally speaking, although it is obvious to see the seeking of prosperity value in Yen Fu's early thought of constitutional politics, in fact, the value of freedom and order has already appeared in his mind which are invisible at that time. The value of prosperity is both the strongest voice of the time and the visible aim value of constitutionalism that he in his early life and other intellectuals has proposed. In a series of official calls to arms and enlightening translation books which exhibited his thought of constitutional politics, he creatively explained the value of prosperity, freedom and order. As the first person to input the Western liberal values in modern China, he attached more importance on the prosperous values and began to think about the value of freedom and order in his early time. Then in the mid-term, he returned to the freedom value and talked more about personal freedom and political freedom. Finally, he considered in the late period that order would be the first important task for us at present if the problems of private army regime having appeared after the revolution of 1911 and completing the social reform under the new system and subsequently realizing freedom and eternal prosperity were solved. There are an end wise static value system and a laterally dynamic value relationship in his thought of constitutional politics. In the end wise static value system, the prosperity is the factological value which is properly existing in the situation of saving the nation from extinction; order is the ideological value, which is aiming at the confusion of the early republic of China. The real condition people are living in and the constitutional government; besides, it naturally comes from the needs of the orderly development of the nation and the eternal prosperity. The freedom is the mythological value, which is the ultimate reason why prosperity and freedom are necessary. The value of prosperity, freedom and order in the lateral dynamic value system is dialectical subjects which can mutually promote and are all relying on each other. The unilateral relationship between means and goals only leads to the destruction of three sides. All in all, on one hand, this thesis wishes to be analyzed from his constitutionalism thought to understand the varying features of inner motivation - the change of the aim value with the passing time that owned by the intellectuals who are on the stage of constitutional politics at the end of Qing dynasty from the point to area. In turn, we can also understand the constitutional practice of our predecessors better through the values they have paid attention to. On the other hand, the current practice of constitutional democracy in the process of democratization also requires that society can condense the value consensus to promote the political reform of socialism with Chinese characteristics together. In addition, it needs to find the basic accordance of value ideas from the commendable experimental field of the one hundred constitutional politics which contain untiring efforts of our predecessors.

\section{Acknowledgements}

The research is supported by Research Fun of Southwestern University (No. SWU1209301).

\section{References}

[1] Wang, C. (1986) The Collection of Yanfu’s Work. Zhonghua Book Company, Beijing.

[2] de Montesquieu, B. (Translated by Zhang, Y.S.) (1959) The Spirit of the Laws. Vol. 1, The Commercial Press, Beijing, 155-156.

[3] Stan, P. and Shad, J. (Translated by Wang, X.P.) (2004) The Value of Law in Western Society. China Legal System Press, Beijing, 9-13.

[4] Sun, Y.X. (2003) The Chronicle of Yan Fu. Fujian People’s Publishing House, Fu Zhou, 377-382. 